\title{
Isolation and characterization of bacterial strains with a hydrolytic profile with potential use in bioconversion of agroindustial by-products and waste
}

\author{
Cintia Anabela MAZZUCOTELLI ${ }^{1,2 \star}$, Alejandra Graciela PONCE ${ }^{1,2}$, \\ Catalina Elena KOTLAR ${ }^{1,2}$, María del Rosario MOREIRA ${ }^{1,2}$
}

\begin{abstract}
There is a trend towards the use of novel technologies nowadays, mainly focused on biological processes, for recycling and the efficient utilization of organic residues that can be metabolized by different microorganisms as a source of energy. In the present study the isolation of bacterial strains from six different agro-industrial by-products and waste was performed with the objective of evaluating their hydrolytic capacities and suitability for use in bioconversion of specific substrates. The 34 isolated strains were screened in specific culture media for the production of various hydrolytic enzymes (lipase, protease, cellulase, and amylase). It was found that 28 strains exhibited proteolytic activity, 18 had lipolytic activity, 13 had caseinolytic activity, 15 had amylolytic activity, and 11 strains exhibited cellulolytic activity. The strains that showed the highest hydrolytic capacities with biotechnological potential were selected, characterized genotipically, and identified as Bacillus, Serratia, Enterococcus, Klebsiella, Stenotrophomonas, Lactococcus, and Escherichia genera. It was concluded that the strain isolates have a high potential for use in the bioconversion of agro-industrial waste, both as a pure culture and as a microbial consortium.
\end{abstract}

Keywords: hydrolytic profile; waste management; bioconversion.

\section{Introduction}

Agro-industrial residues are the most abundant and renewable resources on earth. Biomass accumulation in large quantities every year results not only in the deterioration of the environment, but it also causes loss of potentially valuable material which could be processed and converted into various different value-added products. These waste materials are packed with a tremendous source of energy and nutrients (proteins, carbohydrates, lipids, etc.), which would otherwise be lost if they are disposed as such in the open dumps and landfills (NIGAM; PANDEY, 2009; OKONKO et al., 2009).

Depending on the nature of the industrial by-products or waste, this would allow obtaining products with higher digestibility and nutritional value, destined to both human and animal food (NORTEY et al., 2007; OKONKO et al., 2009). Additionally, it would be possible to use them as renewable carbon sources in large scale fermentation processes. Another alternative could be its utilization as raw-material for the production of high-value products. In recent years, there has been a marked trend towards the use of novel technologies, mainly focused on biological processes, for recycling and efficient utilization of organic residues (NIGAM; PANDEY, 2009; OKONKO et al., 2009).

Biotechnological processes such as solid substrate fermentation offer great opportunities for the reuse of abundant agricultural by-products and waste in manufacturing other products (VISHWANATHA et al., 2010; MUTHULAKSHMI et al., 2011). These residues are generally considered the best substrates for the solid substrate fermentation processes (PANDEY et al., 1992). The major natural organic materials available are polymeric, e.g. polysaccharides (cellulose, hemicellulose, pectins, starch etc.), lignin, and protein, which can be metabolized by different microorganisms as a source of energy through enzymatic hydrolysis. While there is a wide diversity of microorganism producing hydrolytic enzymes, including bacteria, yeast, and fungi, the use of indigenous microorganisms (waste native microflora) ensures efficient activity, acting in an environment to which it is adapted (PONCE; MOREIRA; ROURA, 2008).

A large number of industrial processes utilize microbial enzymes, and new areas of application have constantly been added. Enzymes can modify and improve the functional, nutritional, and sensory properties of ingredients and products, and they are also used as alternatives to traditional chemical processes (PANDEY et al., 1992; KIRK; BORCHERT; FUGLSANG, 2002). In others words, their utilization enables the removal of chemicals used for food processing and the minimization of waste, facilitates processes which may otherwise be impractical or uneconomic, enhances nutrition and texture, and extends shelf life of products (WHITEHURST; VAN OORT, 2009).

For the above mentioned reasons, the effective use of these industrial by-products and waste could serve several purposes such as value-added products, waste management, and production of enzymes with potential industrial application.

\footnotetext{
Received 8/8/2012

Accepted 15/2/2013 (005819)

Grupo de Investigación en Ingeniería en Alimentos, Universidad Nacional de Mar del Plata, Juan B. Justo 4302, CP B7608FDQ, Mar del Plata, Provincia de Buenos Aires,

Argentina, e-mail: cmazzuco@fi.mdp.edu.ar

${ }^{2}$ Consejo Nacional de Investigaciones Científicas y Técnicas - CONICET, Argentina

${ }^{*}$ Corresponding author
} 
The aim of this study is to isolate and characterize bacterial strains from regional agro-industrial by-products and waste by determining their ability to produce hydrolytic enzymes (lipase, protease, cellulase, and amylase) and their potential for use as a microbial consortium in the bioconversion of agro-industrial waste.

\section{Materials and methods}

\subsection{Source of microorganisms}

Microorganisms were isolated from: (a) dried defatted wheat germ (DDWG) and (b) undried defatted wheat germ (UDWG) supplied by the pilot plant of Facultad de Ingeniería, Universidad Nacional del Centro, Provincia Buenos Aires (Argentina); (c) defatted soy pellet (DSP) and (d) sunflower meal (SM) supplied by an industrial plant which produces edible oils (Cargill, Quequén, Argentina); (e) cheese whey (CW) supplied by a pilot plant which produces cheese (Universidad de Buenos Aires, Argentina); and (f) brewer's spent grain (BSG) supplied by Antares S.A. (Mar del Plata, Argentina). All of the samples were taken under sterile conditions, placed in sample bags, and transported to the laboratory aseptically. Until use, they were maintained under sterile conditions at room temperature.

\subsection{Microorganism isolation}

$10 \mathrm{~g}$ of samples were blended with $70 \mathrm{~mL}$ of peptone water in a Stomacher (400 Circulator Homogenizer). The samples were serially diluted and plated onto Plate Count Agar (PCA) (Laboratorios Britania S.A., Buenos Aires, Argentina). The plates were incubated at $35^{\circ} \mathrm{C}$ for $24-48$ hours. After incubation, the different colonies with specific morphological characteristics were collected and transferred to Nutrient Broth (NB), (Britania, Argentina) in order to isolate the microorganisms from different industrial waste.

\subsection{Microorganism culture and enzyme source}

The isolated cultures were maintained on soft Brain and Heart agar (BH) (Britania, Argentina) (3.5\% w/v of agar- agar) at $-18^{\circ} \mathrm{C}$. Subcultures were made every 6 months.

The strains were activated in two steps. First, a loop of each culture was inoculated in $10 \mathrm{~mL}$ NB with $0.1 \%$ of Tween- 80 and incubated at $35{ }^{\circ} \mathrm{C}$ for $24-48$ hours; subsequently, $2 \mathrm{~mL}$ of active culture were centrifuged at $1000 \mathrm{rpm} / 3 \mathrm{~min}$. at $4{ }^{\circ} \mathrm{C}$. The obtained precipitate was added to $10 \mathrm{~mL}$ fresh $\mathrm{NB}+0.1 \%$ Tween- 80 and statically incubated.

Cell-free supernatants were, however, obtained by culture centrifugation at $10,000 \mathrm{rpm} / 15 \mathrm{~min}$. at $4{ }^{\circ} \mathrm{C}$. This cell-free culture supernatants were used as the crude enzyme extract (CEE).

\subsection{Enzymatic activity assay}

The different enzymatic activities of the selected strains were measured using the agar diffusion method on $\mathrm{BH}$ agar (MOREIRA et al., 2005). Wells of $5 \mathrm{~mm}$ diameter were cut under sterile conditions into specific agar plates. $35 \mu \mathrm{L}$ of CEE was placed into each well. These plates were incubated aerobically at $35^{\circ} \mathrm{C} / 48$ hours, with the exception of lipolytic activity plates, which were incubated for 72 hours. After incubation, the diameter of the halo or clear zone formed around de well was measured in order to quantify enzyme activity.

\subsection{Specific media}

\section{Extracellular protease activity}

Qualitative protease activity assay was evaluated on Modified Basal Medium (MM) that contained (per liter): $1 \mathrm{~g}$ glucose, 2.5 g yeast extract and $14 \mathrm{~g}$ agar-agar supplemented with $6.2 \mathrm{~g} / \mathrm{L}$ skim milk protein $(5 \mathrm{~g} / \mathrm{L}$ of casein) (PÉREZ BORLA; DAVIDOVICH; ROURA, 2009). The formation of clear zone (12 $\mathrm{mm}$ or more) in the medium surrounding the well indicated positive protease activity (PÉREZ BORLA; DAVIDOVICH; ROURA, 2009).

\section{Caseinolytic activity assay}

The strains were screened for caseinase activity on MM supplemented with $1 \%$ casein. Positive caseinolytic activity was detected by the formation of a turbidity zone (white halo) surrounding the well (12 $\mathrm{mm}$ or more) (PÉREZ BORLA; DAVIDOVICH; ROURA, 2009).

\section{Lipolytic activity assay}

Qualitative lipase activity assay was evaluated on Agar Tween medium which contained (per liter): $10 \mathrm{~g}$ peptone, $0.1 \mathrm{~g} \mathrm{CaCl}_{2} .2 \mathrm{H}_{2} \mathrm{O}, 5 \mathrm{~g} \mathrm{NaCl}, 10 \mathrm{~mL}$ Tween 80 , and $15 \mathrm{~g}$ agaragar at $\mathrm{pH}$ of 7-7.4 (HARRIGAN, 1998). The formation of a white precipitate around the well resulting from the deposition of crystals of the calcium salt formed by the fatty acid liberated by the enzyme, indicates positive lipolytic activity $(7 \mathrm{~mm}$ or more) (GOPINATH; ANBU; HILDA, 2005).

In order to discriminate the microorganisms in "true" lipases and esterase producer, the microorganisms with positive lipase activity in Agar Tween were sub-cultured in a modified Rhodamine medium, according to Kouker and Jaeger (1987). The basal medium contained (per liter): $8 \mathrm{~g}$ nutrient broth, $4 \mathrm{~g}$ sodium chloride, $10 \mathrm{~g}$ agar, and $250 \mu \mathrm{L}$ Tween 80 . The $\mathrm{pH}$ of the medium was adjusted to 7.0; it was autoclaved and cooled to about $60^{\circ} \mathrm{C}$. Then, $30 \mathrm{~mL}$ of olive oil (previously thermally treated in a culture oven at $80{ }^{\circ} \mathrm{C} / 20 \mathrm{~min}$.) and $10 \mathrm{~mL}$ of rhodamine $B$ solution ( $1: 1 \mathrm{w} / \mathrm{v}$, in sterile distilled water) were sterilized by filtration $(0.22 \mu \mathrm{m})$ an added to the basal medium with vigorous stirring and emulsified by mixing for 1 minute with an Ultra-Turrax homogenizer. The final culture medium was allowed for 10 minutes rest at $60{ }^{\circ} \mathrm{C}$ to reduce foaming, and then $20 \mathrm{~mL}$ of medium were poured into each petri dish. Agar plates containing trioleoylglycerol and Rhodamine B appeared opaque and pink. Lipase production was monitored by irradiating plates with UV light at $350 \mathrm{~nm}$. After 24-48 hours of incubation, the bacterial culture with "true lipases" presented an orange fluorescence. 


\section{Amylolytic activity assay}

The cultures were screened for their ability to hydrolyze starch on MM supplemented with $1 \%$ soluble starch as substrate. After incubation, the plates were flooded with $1 \%$ iodine in $2 \%$ KI. The clear zones around the well ( $8 \mathrm{~mm}$ or more) indicated a positive amylase activity.

\section{Cellulolytic activity assay}

The strains were screened for cellulase activity on MM with 1\% CMC (carboxymethyl-cellulose) as substrate. After incubation, the plates were stained with Congo red dye and washed. A positive cellulase activity was detected by the formation of a yellow halo ( $8 \mathrm{~mm}$ or more) against a red background.

\subsection{Characterization of hydrolytic strains}

For characterization by ribosomal DNA genes analysis, the genomic DNA of the hydrolytic strains was extracted from cells grown overnight and was used for in vitro amplification of almost full-length 16S rRNA gene fragments using eubacterial primers: 16S-fw(TGCCAGCAGCCGCGGTAATAC) and 16S-rv(CGCTCGTTGCGGGACTTAACC). The resulting PCR products from agarose gel were purified using a purification kit (Amersham). Sequences were compared with other released sequences in the GenBank database using BLAST program (National Center for Biotechnology Information) (ALTSCHUL et al., 1997).

\subsection{Antagonism test}

The test was performed intercrossing the previously selected strains using the methodology detailed below. The well diffusion method was used according to Moreira et al. (2005). The strains were grown in BHI and statically incubated for 24 hours at $35^{\circ} \mathrm{C}$. The indicator bacterium (one of the hydrolytic strains under test) was spread uniformly on the surface of BHI. Circular wells (5 $\mathrm{mm}$ in diameter) were punched out into these agar plates under sterile conditions. The supernatant culture (10,000 rpm; 20 minutes) of the other hydrolytic microorganisms was used to evaluate antagonistic properties. An aliquot $(35 \mu \mathrm{L})$ of each supernatant was transferred into each well. The plates were incubated at $35{ }^{\circ} \mathrm{C}$ for $24-48$ hours. The formation of an inhibition zone around the well indicated the production of antagonist substances. The inhibition halo diameter was measured. The results were considered positive when the inhibition halo diameter was $>8 \mathrm{~mm}$.

\subsection{Statistical analysis}

The enzymatic activity assay of the isolated strains was performed in triplicate with three independent replicates. The results were reported as mean \pm standard deviation. Statistical significance of the differences between the mean values was assessed by one-way ANOVA with R software (2.14.0 software version). The Tukey test, a multiple comparison procedure, was used to compare the means. The values were considered significantly different from each other at $\mathrm{P}<0.05$.

\section{Results and discussion}

\subsection{Isolation and hydrolytic profile determination}

Thirty-four bacterial isolates were obtained from six different industrial by-products and waste (Table 1). These strains were screened on specific culture media with respect to hydrolytic enzymes production. Ten strains were isolated from dried defatted wheat germ (DDWG), and the main hydrolytic capacities presented by them were lipase and protease activity ( $80 \%$ and $50 \%$, respectively). Six strains were obtained from undried defatted wheat germ (UDWG) showing a hydrolytic pattern similar to that of the isolates from the previous substrate ( $83 \%$ proteolytic and $50 \%$ lipolytic strains). With regards to the 5 strains isolated from cheese whey $(\mathrm{CW}), 80 \%$ of these strains showed proteolytic and $60 \%$ had lipolytic capacity. Only 3 strains of sunflower meal (SM) were isolated, and all of them showed proteolytic capacity and none presented a cellulolytic pattern. Of the six strains isolated from defatted soy pellet (DSP), the main hydrolytic capacities observed were protease, amylase, and lipase enzyme producers $(80 \%, 67 \%$, and $67 \%$, respectively). Four strains were isolated from brewer's spent grain (BSP), of which $75 \%$ showed proteolytic and 50\% exhibited amylolytic capacity. The percentage of cellulase producing isolates from the six residues was smaller than that of one of the other enzymes $(<50 \%)$.

According to Muthulakshmi et al. (2011), the results obtained suggest that the hydrolytic profile of each isolated strain is directly related to the substrate from which it is obtained. The probability of finding an organism with a particular hydrolytic capacity increases since the isolation is performed from a waste rich in the substrate of the enzyme of interest (VISHWANATHA et al., 2010). The same methodology used in the present study has been followed for the isolation of microorganisms with specific capacities: effluents of dairy and meat processing industry for the isolation of microorganisms producers of both lipases and proteases (SANGEETHA; GEETHA; ARULPANDI, 2008); soil contaminated with oil, oilseeds, and dairy effluents for the isolation of lipase-producing strains; and tannery effluent for the isolation of protease producing microorganisms (SIVA MUTHUPRAKASH; JAYANTHI ABRAHAM, 2011).

Table 1. Strains isolated from agro-industrial by-products and waste.

\begin{tabular}{cccccc}
\hline DDWG & UDWG & DSP & SM & CW & BSG \\
\hline GIIA6 & GIIA1 & GIIA7 & GIIA3 & GIIA8 & GIIA5 \\
GIIA13 & GIIA2 & GIIA9 & GIIA17 & GIIA16 & GIIA23 \\
GIIA15 & GIIA12 & GIIA10 & GIIA28 & GIIA21 & GIIA24 \\
GIIA20 & GIIA14 & GIIA11 & & GIIA25 & GIIA34 \\
GIIA22 & GIIA26 & GIIA18 & & GIIA27 & \\
GIIA30 & GIIA29 & GIIA19 & & & \\
GIIA31 & & & & & \\
GIIA32 & & & & & \\
GIIA4 & & & & & \\
GIIA33 & & & &
\end{tabular}

DDWG: Dried defatted wheat germ; UDWG: Undried defatted wheat germ; DSP: Defatted soy pellet; SM: Sunflower meal; CW: Cheese whey; BSG: Brewer's spent grain. 
Figures 1-5 show the different hydrolytic profiles of the 34 isolated strains from the agro-industrial waste. The Tukey's multiple comparison test was used to compare the means. Means with the same letter are not significantly different. Among the strains tested, the majority of the isolates showed extracellular multi enzyme activity. It is also important to note that the strains GIIA7 and GIIA9, both isolated from DSP, showed activity with all substrates. Microorganisms that exhibit two or more hydrolytic capacities constitute an important resource for the recycling or reprocessing of industrial waste and by-products.

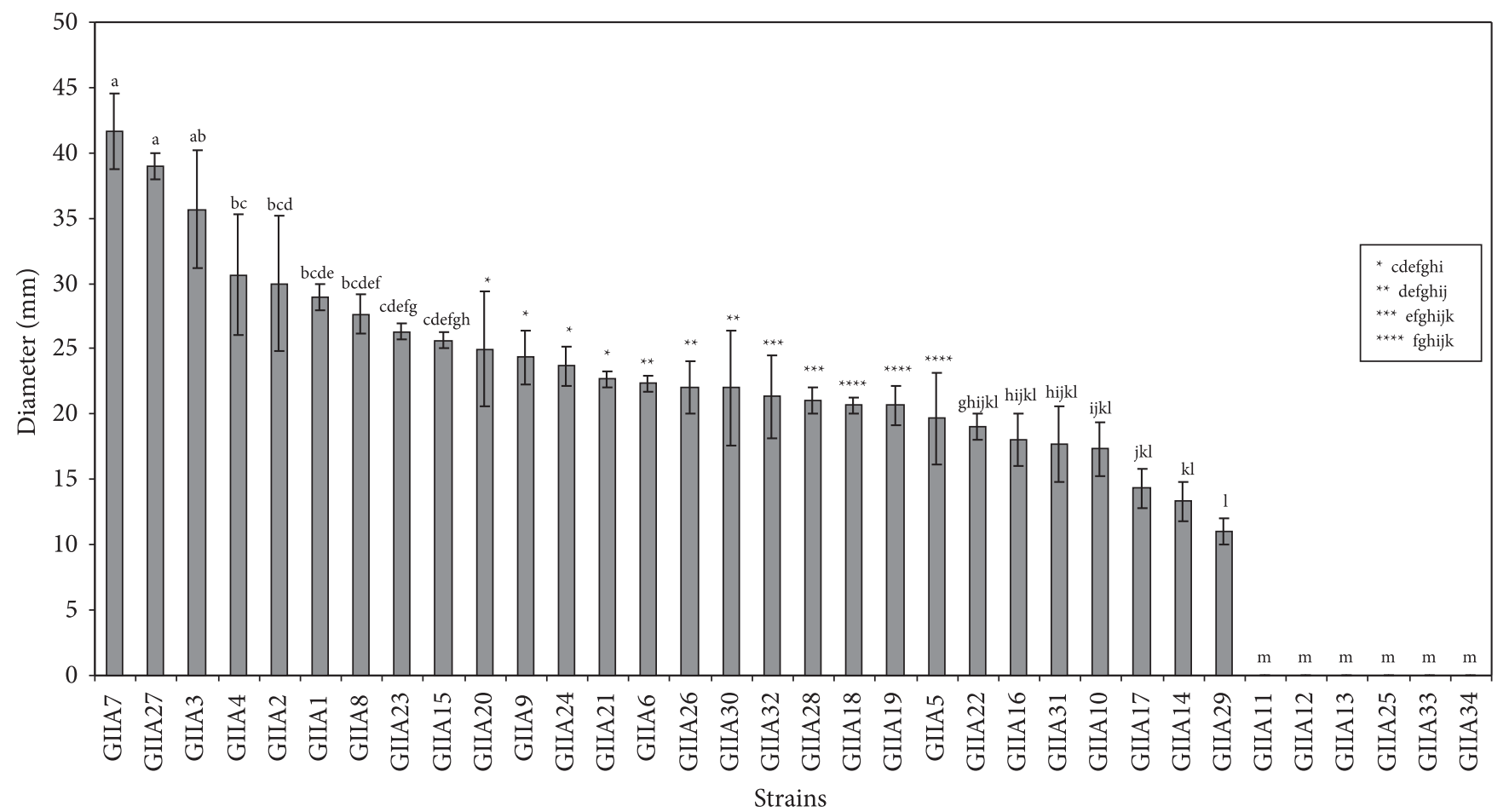

Figure 1. Protease activity of isolated strains. Means with the same letter are not significantly different according to the Tukey's multiple comparison test $(\mathrm{P}<0.05)$. Values are the means \pm standard deviations $(\mathrm{n}=3)$.

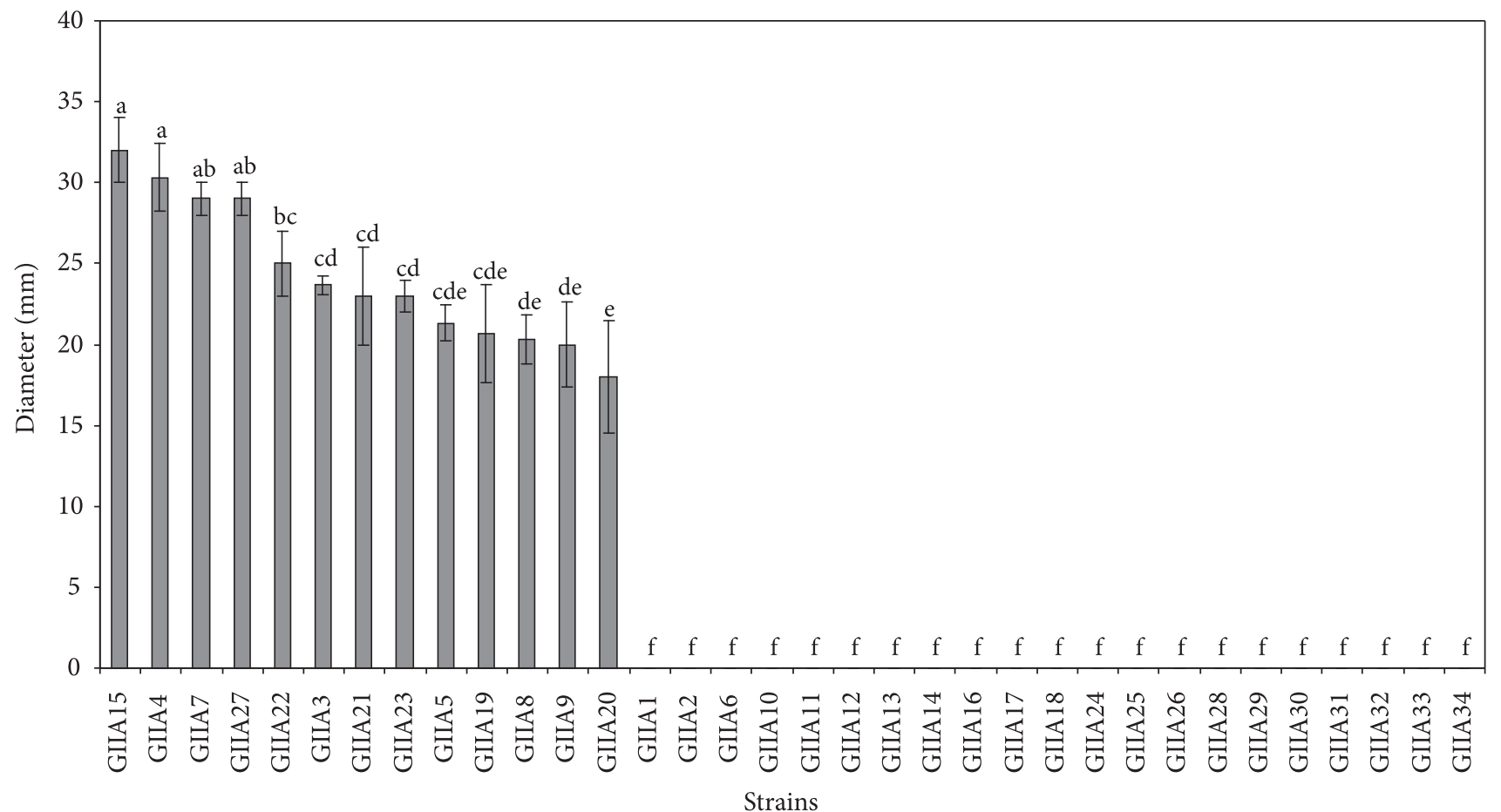

Figure 2. Caseinase activity of isolated strains. Means with the same letter are not significantly different according to the Tukey's multiple comparison test $(\mathrm{P}<0.05)$. Values are the means \pm standard deviations $(\mathrm{n}=3)$. 
The ten strains (indicated by the letter "a" in Figures 1 to 5) were significantly different $(\mathrm{P}<0.05)$ compared to the other evaluated strains. These strains, GIIA2, GIIA3, GIIA4, GIIA7, GIIA9, GIIA15, GIIA16, GIIA20, GIIA23, and GIIA27 showed the highest hydrolytic capacities with biotechnological potential. Then, the selected strains were characterized by ribosomal DNA genes analysis and were identified phylogenetically as belonging to the Bacillus, Serratia, Enterococcus, Klebsiella, Stenotrophomonas, Lactococcus, and Escherichia genera (Table 2). The ten identified strains presented

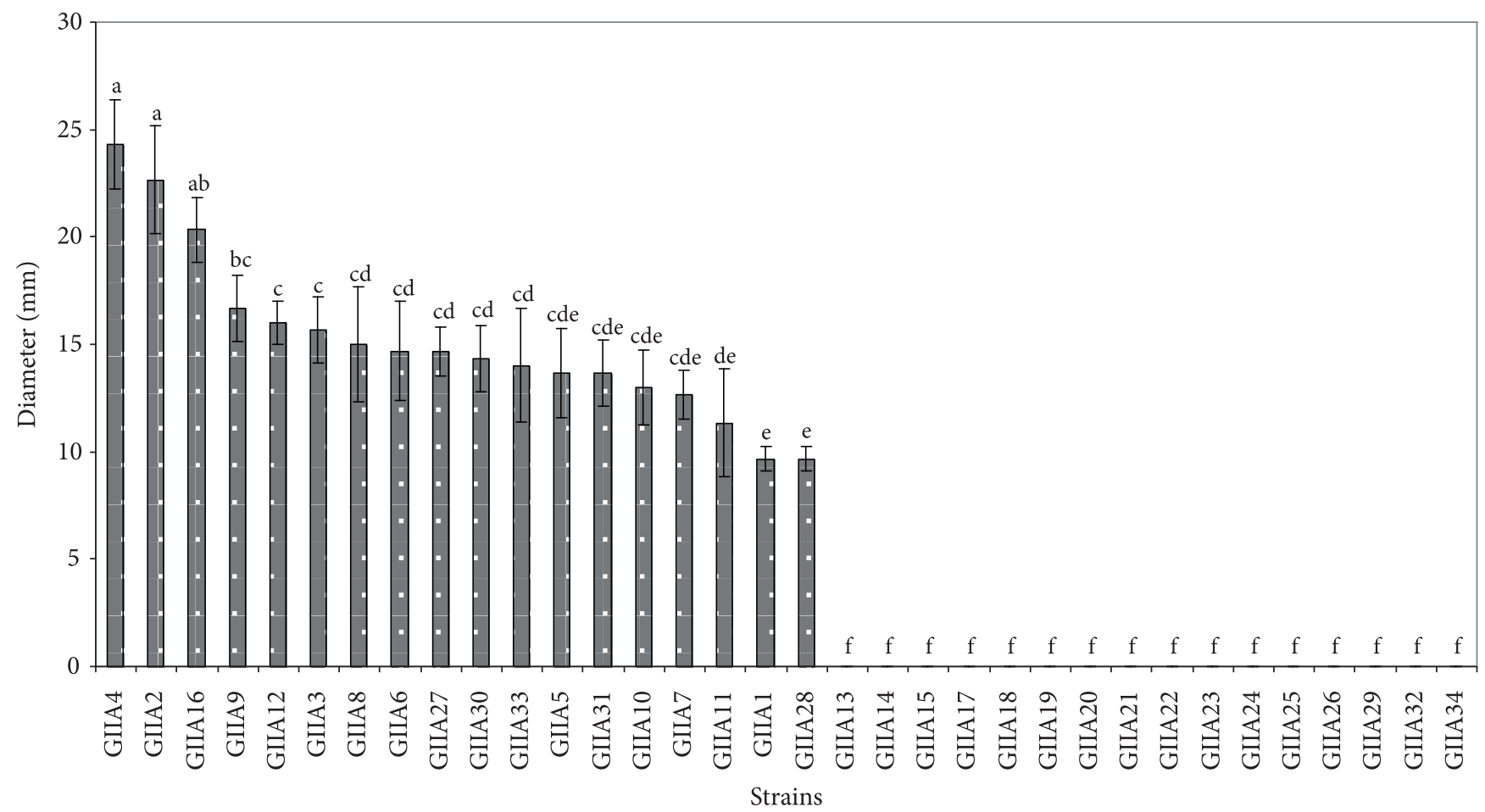

Figure 3. Lipase activity of isolated strains. Means with the same letter are not significantly different according to the Tukey's multiple comparison test $(\mathrm{P}<0.05)$. Values are the means \pm standard deviations $(\mathrm{n}=3)$.

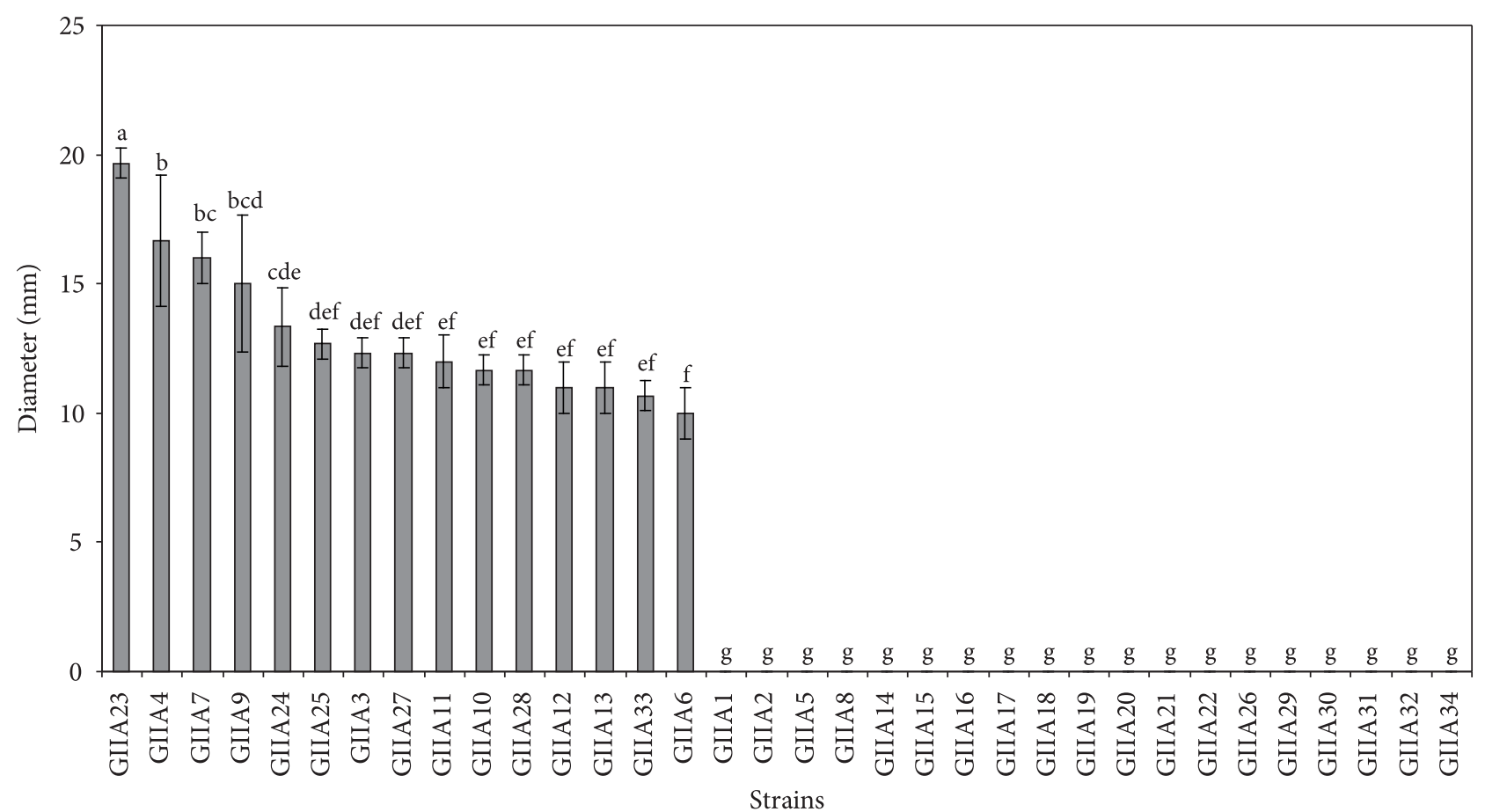

Figure 4. Amylase activity of isolated strains. Means with the same letter are not significantly different according to the Tukey's multiple comparison test $(\mathrm{P}<0.05)$. Values are the means \pm standard deviations $(\mathrm{n}=3)$. 


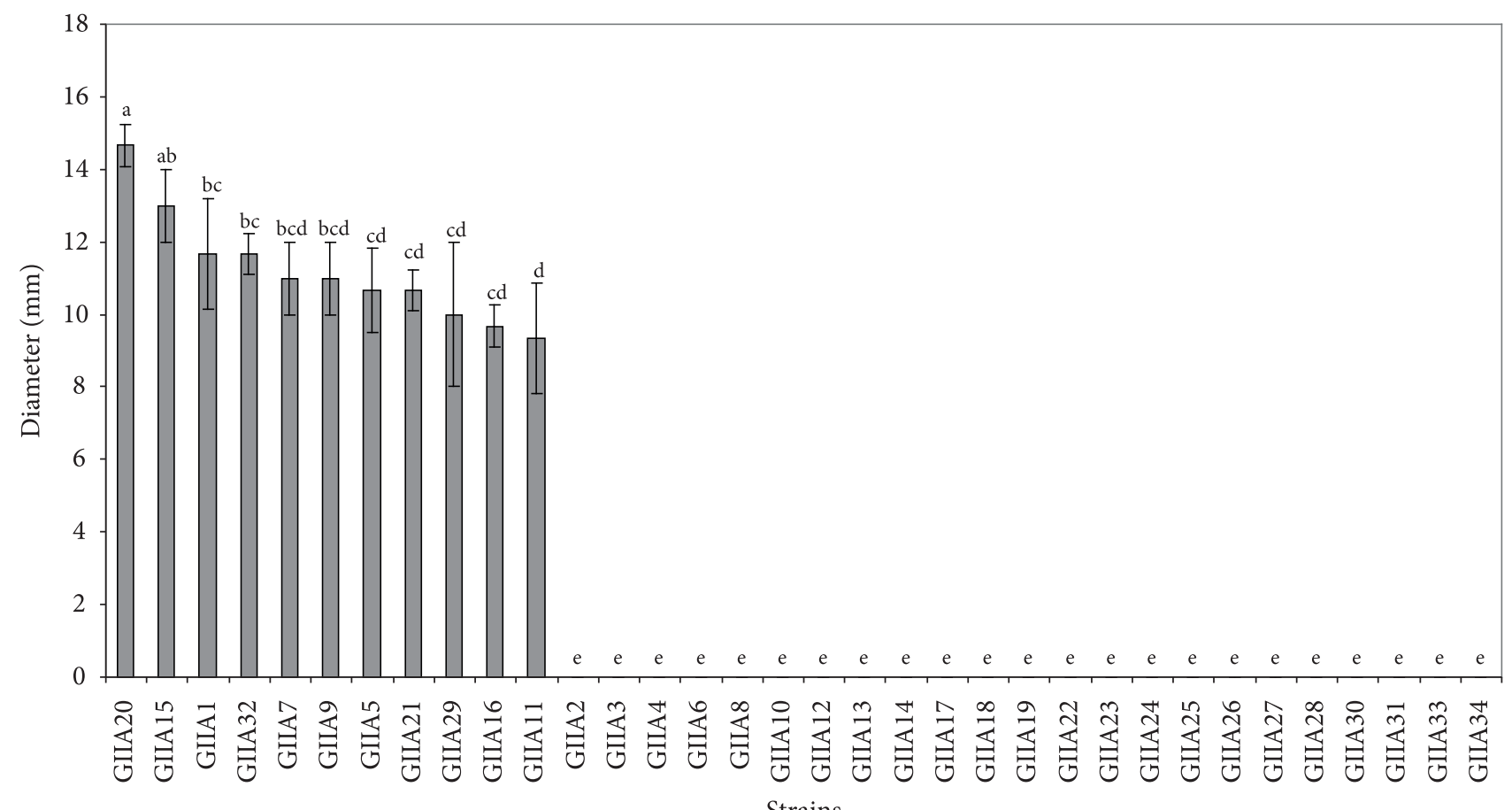

Figure 5. Cellulase activity of isolated strains. Means with the same letter are not significantly different according to the Tukey's multiple comparison test $(\mathrm{P}<0.05)$. Values are the means \pm standard deviations $(\mathrm{n}=3)$.

Table 2. Source and phylogenetical identification of the selected strains.

\begin{tabular}{cccc}
\hline Strain & Name of closest related species ${ }^{\mathrm{a}}$ & Similarity $^{\mathrm{a}}(\%)$ & Accession number $^{-}$ \\
\hline GIIA4 & Serratia liquefaciens strain M11 & 99 & JN596115.1 \\
GIIA15 & Lactococcus garvieae strain LG-ilsanpaik-gs201105 & 97 & JN162117.1 \\
GIIA20 & Enterococcus faecalis strain HN-N2 & 99 & FJ378657.2 \\
GIIA2 & Serratia proteamaculans & 99 & EF526505.1 \\
GIIA3 & Serratia sp. W2Dec25 & 99 & JN106438.1 \\
GIIA7 & Bacillus thuringiensis strain DW-1T & 99 & EU240956.1 \\
GIIA9 & Stenotrophomonas sp. DIV102 & 99 & FN547780.1 \\
GIIA16 & Klebsiella sp. strain FDY12 & 98 & HE612112.1 \\
GIIA27 & Enterococcus durans strain PL25 & 99 & JN792514.1 \\
GIIA23 & Escherichia coli strain FDY10 & 98 & HE605049.1 \\
\hline
\end{tabular}

${ }^{a}$ Based on a Blast search of the NCBI database.

multienzyme capacities, highlighting Bacillus thuringiensis and Stenotrophomonas sp. showing hydrolytic capacity with the 5 substrates. It is also important to mention that $60 \%$ of the microorganisms identified showed enzymatic activity with 4 or more substrates, and that $40 \%$ of them combine two high hydrolytic capacities (Table 3 ).

In agreement with our results, Klebsiella sp. has been reported for many researchers to be a source of lipolytic enzymes (WANG; CHEN; TSAI, 2006; SANGEETHA; ARULPANDI; GEETHA, 2011). Strains of Klebsiella sp. have been isolated from diverse sources, for example from soil samples (JALASUTRAM; JETTY; ANUPOJU, 2011), from tannery effluent of leather industries (SIVASHANMUGAM; JAYARAMAN, 2011), or from an off-shore oil field (CHAMKHA et al., 2011).
Another genus found was Stenotrophomonas sp. While soil and plants are its main environmental reservoir (RYAN et al., 2009), this bacterium has also been isolated from diverse effluent treatment plants and wastewater (YU; LIU; WANG, 2009; VERMA et al., 2010) and from a Brazilian sugar cane variety (RAMOS et al., 2011). In agreement with the results obtained, some researchers have described the production of extracellular enzymes by Stenotrophomonas including proteases, lipases, nucleases, and chitinases (TRAVASSOS et al., 2004; KUDDUS, RAMTEKE, 2011). Stenotrophomonas sp. has many traits that could be used in different biotechnological processes, and it also has promising applications in bioremediation and phytoremediation (RYAN et al., 2009).

Serratia strains were isolated from defatted wheat germ (undried and dried) and from sunflower meal. Serratia species 
Table 3. Identified strains and their hydrolytic profile.

\begin{tabular}{lccccc}
\hline \multicolumn{1}{c}{ Strain } & Milk & Casein & Starch & Cellulose & Tween \\
\hline Serratia liquefaciens & + & ++ & + & - & + \\
Lactococcus garvieae & + & ++ & - & + & + \\
Enterococcus faecalis & + & + & - & - & - \\
Serratia proteamaculans & + & - & + & + & + \\
Serratia sp. & ++ & + & + & + & + \\
Bacillus thuringiensis & ++ & + & - & + & + \\
Stenotrophomonas sp. & + & - & + & + \\
Klebsiella sp. & + & ++ & ++ & + \\
Enterococcus durans & ++ & + & + & + \\
Escherichia coli & + & + & + & + \\
\hline
\end{tabular}

(-) No significant hydrolytic activity; (+) Significant hydrolytic activity; (++) Highly significant hydrolytic activity.

are found naturally in the environment in water, soil, animals (including man), and also from the surfaces of plants (VENIL; SANGEETHA KAMATSHI; LAKSHMANAPERUMALSAMY, 2009). In addition, Serratia species have been encountered in spoiling foods of vegetable and protein origin. Several researchers argue that most of Serratia sp. isolates from diverse sources are capable of producing extracellular enzymes i.e., amylase, protease, lipase, and chitinase, suggesting that they can be exploited as biocontrol and biodegrading agents (VENIL; SANGEETHA KAMATSHI; LAKSHMANAPERUMALSAMY, 2009). In the present study, the three Serratia strains isolated from agro-industrial waste exhibited a strong proteolytic and lipolytic activity, and two of them exhibited amylolytic capabilities. Similar results were reported by Losantos et al. (2000), who found a psychrotrophic strain of S. liquefaciens that was slightly proteolytic and lipolytic.

Bacillus thuringiensis is one of the isolated strains with a high potential for biotechnological application in different aspects. Many researchers have studied this bacterium because of its great biotechnological interest. Bacillus thuringiensis has been isolated mainly from samples of soil (ÖZTÜRK et al., 2008; SARKER; ROY; YEASMIN, 2010) and soil contaminated with different materials such as grain dust, olive-cultivated soils, waste and industrial-by-products contaminated soils, and animal by-products-contaminated soils (OBEIDAT; HASSAWI; GHABEISH, 2004). In the present study, the presence of Bacillus thuringiensis in defatted soy pellet may be associated to an industrial cross-contamination of these by-products with soil particles. On the other hand, the biotechnological interest also lies in its wide variety of extracellular hydrolytic enzymes (TENORIO-SÁNCHEZ et al., 2010). In accordance with the results obtained in the present study, other researchers found strains of $B$. thuringiensis with a variety of enzymes capacities, such as proteases, amylases, esterases, and chitinases (TENORIO-SÁNCHEZ et al., 2010). In spite of the potential biotechnological use of these enzymes, this subject has been scarcely studied (TENORIO-SÁNCHEZ et al., 2010).

The genus Enterococcus is the most controversial group of lactic acid bacteria (FOULQUIÉ MORENO et al., 2006). Enterococci occur in many different habitats such as soil, surface waters, and ocean water, but their primary habitat is the intestine of warm-blooded animals (MARTÍN-PLATERO et al., 2009; FRANZ et al., 2011). However, due to its aptitude to resist or grow in hostile environments such as extreme $\mathrm{pH}$, temperatures, and salinity, Enterococcus can be found in many foods such as milk, cheese, fermented sausage, and fermented olives (GIRAFFA, 2003; MARTÍN-PLATERO et al., 2009). This explains the presence of enterococci in samples of CW and DDWG. Contrary to other lactic acid bacteria, enterococci are not "Generally Recognized as Safe" (GRAS) (OGIER; SERROR, 2003). Enterococci are generally considered as having an ambiguous status concerning their safety assessment procedure. Nevertheless, the use of Enterococci in foods as commercial starters and probiotic strains should be possible on the basis of case-by-case studies establishing their safety or at least the lack of acquired antibiotic resistance genes and proven virulence factors (OGIER; SERROR, 2003).

Similarly, Lactococcus garvieae is another debated strain. Even though most of the group of Lactic Acid Bacteria is generally recognized as safe by the US Food and Drug Administration, their association with fish disease has been reported (FRANÇOISE, 2010). In samples of Zabady, the most popular fermented milk in Egypt, S. thermophilus and L. garvieae species were shown to be the dominant microflora (EL-BARADEI; DELACROIX-BUCHET; OGIER, 2008). Recently, L. garvieae has also been isolated from fecal samples of healthy people, suggesting that this microorganism could be part of the human commensal microbiota or transient bacteria ingested with food (AGUADO-URDA et al., 2010).

Escherichia coli belongs to the Enterobacteriaceae family. Within the species of Escherichia coli, there are commensal strains and a variety of pathogenic strains, which are distinguished from normal flora by their possession of virulence factors such as exotoxins (ROVID SPICKLER et al., 2010). The presence of $E$. coli in the brewer's spent grain sample probably results from fecal contamination of the raw material. Vegetables may become contaminated at any time during their production, harvesting, and processing. It would be necessary to assess the absence of virulence factors in the isolated strain to evaluate its possible application in an agro-industrial byproduct or waste since its enzymatic capacity has characteristics of interest. 


\subsection{Antagonism test}

Antagonistic activity of the strains Lactococcus garvieae and Enterococcus faecalis against Stenotrophomonas sp. was detected (inhibition diameters of 14 and $12 \mathrm{~mm}$ respectively). The formation of growth inhibition halo around the wells corresponds to the other strains was not observed.

The test of compatibility between the selected strains is useful to define the composition of potential mixed culture. According to the results of the antagonism test, in future assays, the combinations of no-antagonistic strains that could produce the optimum waste hydrolysis could be applied. According to some authors (LOPERENA et al., 2009), the degrading capacity of a microbial consortium is usually higher than that of any of the individual strains that compose it since often this capacity depends on the cooperation activities that occur within microbial consortia. It was concluded that among the 10 strains isolated from industrial waste and byproducts, only Stenotrophomona sp. was inhibited for the strains Lactococcus garvieae and Enterococcus faecalis. Therefore, all other possible combinations would be suitable for obtaining a microbial consortium, which enhances the hydrolysis of residues of interest.

The significant hydrolytic capacities exhibited by strains characterized by PCR demonstrate its potential for application in the bioconversion and reutilization of agro-industrial byproducts and waste, both as a pure culture or mixed culture as a microbial consortium.

\section{Conclusions}

The main advantage of using a variety of industrial waste with different characteristics and compositions for bacterial strains isolation is that it extends the range of possibilities to obtain microorganisms with different hydrolytic profiles. Furthermore, knowing the hydrolytic profile of isolates allows a preliminary selection of strains to be used on a given substrate, also allowing the selection of strain combinations that improve the hydrolytic capacities desired according to the characteristics or composition of the waste to which these hydrolytic bacteria will be added.

Regarding the isolates, it is important to know the characteristics and behavior of each isolated genus before their application on a particularly industrial waste. In addition, depending on the final destination of the process (animal or human food, obtaining enzymes, waste degradation, etc.), it would be important to evaluate the use of certain strains that could present virulence factors or confirm the absence of these factors in the isolate.

\section{Acknowledgements}

The authors gratefully acknowledge the financial supported provided by Consejo Nacional de Investigaciones Científicas y Técnicas (CONICET) and Universidad Nacional de Mar del Plata (UNMDP).

\section{References}

AGUADO-URDA, M. et al. Utilization of lactose and presence of the phospho-galactosidase (lacG) gene in Lactococcus garvieae isolates from different sources. International Microbiology, v. 13, p. 189-193, 2010. PMid:21404213.

ALTSCHUL, S. F. et al. Gapped BLAST and PSI-BLAST: a new generation of protein database search programs. Nucleic Acids Research, v. 25, p. 3389-3402, 1997. PMid:9254694 PMCid:146917. http://dx.doi.org/10.1093/nar/25.17.3389

CHAMKHA, M. et al. Isolation and characterization of Klebsiella oxytoca strain degrading crude oil from a Tunisian off-shore oil field. Journal of Basic Microbiology, v. 51, n. 6, p. 580-589, 2011. PMid:22144124. http://dx.doi.org/10.1002/jobm.201100073

EL-BARADEI, G.; DELACROIX-BUCHET, A.; OGIER, J.C. Bacterial biodiversity of traditional Zabady fermented milk. International Journal of Food Microbiology, v. 121, p. 295-301, 2008. PMid:18077039. http://dx.doi.org/10.1016/j. ijfoodmicro.2007.11.014

FOULQUIÉ MORENO, M. R. et al. The role and application of enterococci in food and health. International Journal of Food Microbiology, v. 106, p. 1-24, 2006. PMid:16216368. http://dx.doi. org/10.1016/j.ijfoodmicro.2005.06.026

FRANÇOISE, L. Occurrence and role of lactic acid bacteria in seafood products. Food Microbiology, v. 27, n. 6, p. 698-709, 2010. PMid:20630312. http://dx.doi.org/10.1016/j.fm.2010.05.016

FRANZ, C. et al. Enterococci as probiotics and their implications in food safety. International Journal of Food Microbiology, v. 151, p. 125-140, 2011. PMid:21962867. http://dx.doi.org/10.1016/j. ijfoodmicro.2011.08.014

GIRAFFA, G. Functionality of enterococci in dairy products. International Journal of Food Microbiology, v. 88, p. 215-222, 2003. http://dx.doi.org/10.1016/S0168-1605(03)00183-1

GOPINATH, S. C. B.; ANBU, P.; HILDA, A. Extracellular enzymatic activity profiles in fungi isolated from oil-rich. Mycoscience, v. 46, p. 119-126, 2005. http://dx.doi.org/10.1007/s10267-004-0221-9

HARRIGAN, W. F. Part IV: Schemes for the Identification of Microorganisms. 3rd ed. London: Academic Press, Laboratory methods in food microbiology, 1998. p. 469.

JALASUTRAM, V.; JETTY, A.; ANUPOJU, G. R. Fermentative conversion of raw glycerol into 1,3-propanediol by isolated Klebsiella pneumoniae $141 B$ strain: Optimization of culture variables. African Journal of Biotechnology, v. 10, n. 80, p. 18493-18502, 2011.

KIRK, O.; BORCHERT, T. V.; FUGLSANG, C. C. Industrial enzyme applications. Current Opinion of Biotechnology, v. 13, n. 4, p. 345-351, 2002. http://dx.doi.org/10.1016/S0958-1669(02)00328-2

KOUKER, G.; JAEGER, K. E. Specific and sensitive plate assay for bacterial lipases. Applied Environmental of Microbiology, v. 53, p. 211-213, 1987. PMid:3103532 PMCid:203632.

KUDDUS, M.; RAMTEKE, P. W. Production optimization of an extracellular cold-active alkaline protease from Stenotrophomonas maltophilia MTCC 7528 and its application in detergent industry. African Journal of Biotechnology, v. 5, n. 7, p. 809-816, 2011.

LOPERENA, L. et al. Isolation and selection of native microorganisms for the aerobic treatment of simulated dairy wastewater. Food Microbiology, v. 17, p. 505-512, 2000.

LOSANTOS, A. et al. Characterization of Enterobacteriaceae strains isolated from spoiled dry-cured hams. Food Microbiology, v. 17, n. 5, p. 505-512, 2000. http://dx.doi.org/10.1006/fmic.2000.0350 
MARTÍN-PLATERO, A. M. et al. Characterization and safety evaluation of Enterococci isolated from spanish goats' milk cheeses. International Journal of Food Microbiology, v. 132, p. 24-32, 2009. PMid:19375810. http://dx.doi.org/10.1016/j. ijfoodmicro.2009.03.010

MOREIRA, M. R. et al. Inhibitory parameters of essential oils to reduce a foodborne pathogen. LWT Food Science and Technology, v. 38, p. 565-570, 2005. http://dx.doi.org/10.1016/j.lwt.2004.07.012

MUTHULAKSHMI, C. et al. Production, purification and characterization of protease by Aspergillus flavus under Solid State Fermentation. Jordan Journal of Biological Sciences, v. 4, n. 3, p. 137-148, 2011.

NIGAM, P.; PANDEY, A. Biotechnology for Agro-Industrial Residues Utilization: Utilization of Agro-Residues. 1st ed. Springer, 2009. http://dx.doi.org/10.1007/978-1-4020-9942-7

NORTEY, T. N. et al. Xylanase supplementation improves energy digestibility of wheat by-products in grower pigs. Livestock Science, v. 109, p. 96-99, 2007. http://dx.doi.org/10.1016/j.livsci.2007.01.092

OBEIDAT, M.; HASSAWI, D.; GHABEISH, I. Characterization of Bacillus thuringiensis strains from Jordan and their toxicity to the Lepidoptera, Ephestia kuehniella Zeller. African Journal of Biotechnology, v. 3, n. 11, p. 622-226, 2004.

OGIER, J. C.; SERROR, P. Safety assessment of dairy microorganisms: The Enterococcus genus. International Journal of Food Microbiology, v. 26, p. 291-301, 2008. PMid:17889954. http:// dx.doi.org/10.1016/j.ijfoodmicro.2007.08.017

OKONKO, I. O. et al. Utilization of food wastes for sustainable development. Electronic Journal of Environmental, Agricultural and Food Chemistry, v. 8, n. 4, p. 263-286, 2009.

ÖZTÜRK, F. et al. Isolation and characterization of native Bacillus thuringiensis strains from soil and testing the bioactivity of isolates against Ephestia kuehniella zeller (Lepidoptera: Pyralidae) Larvae. Turkey Journal of Biochemistry, v. 33, n. 4, p. 202-208, 2008.

PANDEY, A. et al. Solid state fermentation for the production of industrial enzymes. Current Science, v. 77, n. 1, p. 149-162, 1992.

PÉREZ BORLA, O.; DAVIDOVICH, L. A.; ROURA, S. I. Isolation and characterization of proteolytic microorganisms from fresh and fermented cabbage. LWT Food Science and Technology, v. 43, n. 2, p. 298-301, 2009. http://dx.doi.org/10.1016/j.lwt.2009.07.006

PONCE, A. G.; MOREIRA, M. R.; ROURA, S. I. Preliminary characterization of bacteriocin-like substances from lactic acid bacteria isolated from organic leafy vegetables. LWT Food Science and Technology, v. 41, p. 432-441, 2008. http://dx.doi.org/10.1016/j. lwt.2007.03.021

RAMOS, P. L. et al. Screening for endophytic nitrogen-fixing bacteria in Brazilian sugar cane varieties used in organic farming and description of Stenotrophomonas pavanii sp. nov. International Journal of Systematic Evolution in Microbiology, v. 61, p. 926-931, 2011. PMid:20495025. http://dx.doi.org/10.1099/ijs.0.019372-0

ROVID SPICKLER, A. et al. Emerging and exotic diseases of animals. 4th ed. CFSPH Iowa State University, 2010. p. 145.

RYAN, R. P. et al. The versatility and adaptation of bacteria from the genus Stenotrophomonas. Natural Review in Microbiology, v. 7, p. 514-525, 2009. PMid:19528958. http://dx.doi.org/10.1038/ nrmicro2163

SANGEETHA, R.; GEETHA, A.; ARULPANDI, I. Optimization of protease and lipase production by Bacillus pumilus SG 2 isolated from an industrial effluent. The Internet Journal of Microbiology, v. 5, n. 2, 2008.

SANGEETHA, R.; ARULPANDI, I.; GEETHA, A. Bacterial Lipases as potential industrial biocatalysts: an overview. Research Journal of Microbiology, v. 6, p. 1-24, 2011. http://dx.doi.org/10.3923/ jm.2011.1.24

SARKER, D.; ROY, N.; YEASMIN, T. Isolation and antibiotic sensitivity of Bacillus thuringinesis strain from dump soil. Malaysian Journal of Microbiology, v. 6, n. 2, p. 127-132, 2010.

SIVA MUTHUPRAKASH, K. M.; JAYANTHI ABRAHAM, P. A comparative analysis of protease producing microbes isolated from tannery effluent. International Journal of Science and Nature, v. 2, n. 1, p. 110-113, 2011.

SIVASHANMUGAM, K.; JAYARAMAN, G. Production and partial purification of extracellular tannase by Klebsiella pneumonia MTCC 7162 isolated from tannery effluent. African Journal of Biotechnology, v.10, n. 8, p. 364-1374, 2011.

TENORIO-SÁNCHEZ, S. A. et al. Characterization of a Bacillus thuringiensis strain isolated from a highly polychlorinated biphenyls contaminated soil. Tecnólog@, v. 3, n. 3, 2010.

TRAVASSOS, L. H. et al. Phenotypic properties, drug susceptibility and genetic relatedness of Stenotrophomonas maltophilia clinical strains from seven hospitals in Rio de Janeiro. Brazil. Journal of Applied Microbiology, v. 96, p. 1143-1150, 2004. PMid:15078532. http:// dx.doi.org/10.1111/j.1365-2672.2004.02248.x

V ENIL, C.; SA NGE THA KA M A T S H I, N . ; LAKSHMANAPERUMALSAMY, P. Statistical optimization of medium components for the production of lipase by Serratia marcescens SB08. The Internet Journal of Microbiology, v. 7, n. $1,2009$.

VERMA, V. et al. Evaluation of genetic and functional diversity of Stenotrophomonas isolates from diverse effluent treatment plants. Bioresource Technology, v. 101, p. 7744-7753, 2010. PMid:20554196. http://dx.doi.org/10.1016/j.biortech.2010.05.014

VISHWANATHA, T. et al. Screening of substrates for protease production from Bacillus licheniformis. International Journal of Engineering Science and Technology, v. 2, n. 11, p. 6550-6554, 2010.

WANG, P.-Y.; CHEN, T.-L.; TSAI, S.-W. Kinetic resolution of (R,S)ethyl 2-chloromandelate in biphasic media using hydrolase of Klebsiella oxytoca. Enzyme Microboly and Technology, v. 39, n. 4, p. 930-935, 2006. http://dx.doi.org/10.1016/j.enzmictec.2006.01.028

WHITEHURST, R. J.; VAN OORT, M. Enzymes in Food Technology. London: John Wiley and Sons, 2009. p. 1-16. http://dx.doi. org/10.1002/9781444309935.ins

YU, L.; LIU, Y.; WANG, G. Identification of novel denitrifying bacteria Stenotrophomonas sp. ZZ15 and Oceanimonas sp. YC13 and application for removal of nitrate from industrial wastewater. Biodegradation, v. 20, n. 3, p. 391-400, 2009. PMid:19002594. http://dx.doi.org/10.1007/s10532-008-9230-2 